\title{
Tracing the metabolic rift in Colombia's greengrocer: an environmental history of the Anaime Valley
}

\author{
RichaRd DOUGHMAN
}

KEYWORDS: Cajamarca (Colombia), environmental history, metabolic rift, arracacha.

JEL CODES: N56, N96, O13, Q15.

his paper stems from research to reconstruct an environmental history of agri-
culture in the Anaime Canyon Valley and better understand the environmental
consequences of having transformed the area into "Colombia's greengrocer". We trace the origins and development of agro-food production and explore how commercial agriculture and dairy operations have transformed the landscape and local ecosystems in the Anaime valley, in light of Marx's concept of metabolic rift. Research is based on archival sources and a participatory reconstruction of the Anaime landscape from the historical memory of the campesinos, or rural inhabitants. The data shows how internal migration, rapid urban growth and improved transportation infrastructure in the valley during the mid-twentieth century hastened the turn toward intensive commercial agriculture. Increasing links to Colombia's urban markets have led to agricultural intensification and specialization in arracacha (Arracacia xanthorrhiza) production in the Anaime Canyon. As a result, soils and ecosystems have been depleted and agriculture depends increasingly on chemical inputs including fertilizers, indicating a growing metabolic rift. 


\section{Rastreando la brecha metabólica en la despensa agrícola de Colombia: una historia ambiental de la cuenca del río Anaime}

\section{PALABRAS CLAVE: Cajamarca (Colombia), historia ambiental, bre- cha metabólica, arracacha.}

\section{CÓDIGOS JEL: N56, N96, O13, Q15.}

ste artículo nace de una investigación que busca reconstruir la historia am-
biental de la agricultura en el cañón de Anaime, para entender las conse-
cuencias ambientales de su conversión en la despensa agrícola de Colombia. Rastrea la producción agroalimentaria en el cañón hasta sus inicios y explora cómo la agricultura comercial y la producción de lácteos han transformado el paisaje y los ecosistemas locales. Las transformaciones en el paisaje de Anaime se analizan a la luz del concepto de brecha metabólica de Marx. La investigación se nutre de datos procedentes de fuentes de archivo y de una reconstrucción participativa del paisaje anaimuno, a partir de la memoria histórica de sus habitantes campesinos. Los datos muestran que la migración interna, la rápida urbanización y las mejoras en la infraestructura de transporte a mediados del siglo $\mathrm{XX}$ aceleraron la intensificación de la agricultura en el cañón. La creciente integración de Anaime a los mercados urbanos de Colombia condujo a la intensificación agrícola y a la especialización en la producción de arracacha (Arracacia xanthorrhiza). Como resultado, los suelos y los ecosistemas se han deteriorado, y la agricultura depende cada vez más de insumos químicos, inchidos fertilizantes, lo que evidencia una creciente brecha metabólica.

Received: 2018-10-08 - Revised: 2019-04-03 - Accepted: 2019-04-18

Richard Doughman [orcid.org/0000-0001-6244-2152] is an Associate Professor at Faculty of Humanities, Arts and Social Sciences, Universidad de Ibagué, Tolima (Colombia). Address: Faculty of Humanities, Arts and Social Sciences, Universidad de Ibagué, cl Carrera, 22 Calle 67, Barrio Ambalá, Ibagué, Tolima (Colombia).E-mail: richard.doughman@unibague.edu.co 


\section{INTRODUCTION}

Cajamarca, Colombia, gained national attention and international press in March of 2017, when in a legally-binding, popular consultation, its citizens voted overwhelmingly to prohibit mining in the municipality. The referendum side-tracked the South-African firm AngloGold Ashanti's largest endeavor in the Americas, La Colosa, an open-cast gold mine already in advanced stages of exploration. In the nearly ten years of organized resistance and direct action leading up to the referendum, discourse centered on defending the territory's natural abundance and agrarian vocation against the threat of environmental destruction posed by open-pit mining. Many of the fiercest opponents of the mine hailed from the Anaime Canyon, the densely cultivated valley that occupies the southern half of Cajamarca and is largely responsible for the municipality's fame as "Colombia's greengrocer" (despensa agricola). This paper stems from research that reconstructs an environmental history of Anaime's agriculture, aiming to better understand the valley's transformation into Colombia's greengrocer and the consequent environmental changes. In doing so, it traces agro-food production back to its origins in the Anaime Canyon and explores how commercial agriculture and dairy operations have reshaped the landscape and local ecosystems. A close eye is kept on the specific impacts wrought by the introduction of new cultivars, farming techniques and technologies, as well as shifts in land tenure and production relations throughout the secular expansion of agriculture and grazing in the valley. Ultimately, the research evidences certain contradictions within a discourse that uncritically pits the life-giving power of agriculture against the desolation of transnational mining; agriculture in the valley today leans ever more heavily on a resource base that historically it has helped to deplete.

Local actors have been the material authors of the transformation of the Anaime Canyon, but their actions have been conditioned by social, economic and political forces operating on a national and, increasingly, international scale. It follows then that while Anaime Canyon sits at the center of the story, recounting how this once-peripheral territory became incorporated into the foodshed of the nation's largest urban markets requires at least a general reckoning of how capitalist development advanced in Colombia throughout the $20^{\text {th }}$ century. Given this wider framework, transformations in Anaime's landscape are analyzed by light of Marx's concept of the metabolic rift, which posits a steady depletion of soil fertility in the countryside, as long-distance food trade breaks the nutrient cycle, removing organic matter from the soil that the city never replenishes.

The present research follows lines laid out in a Marxist tradition of environmental history, situated between O'Connor's (1997) histories of place with their emphasis on how local configurations of capitalist productive forces and productive relations transform na- 
ture, and the historical political ecology of the world-system set out by Hornborg (2007a) and exemplified in the work of Martínez Alier (2007), Bunker (2007) and Moore (2003). This latter body of work concerns itself in particular with unequal ecological exchange between core economies and their respective peripheries, calling attention not only to the unequal economic exchange associated with the transfer of economic surpluses from periphery to core, long documented by dependency theorists, but also to inequalities in the appropriation of nature and the distribution of environmental risks inherent in the exchange of specific commodities, each with its own ecological rucksack (Martínez Alier, 2008; Pérez Rincón, 2006). As Hornborg (2007b) stresses, the size and characteristics of the ecological rucksack depend on the material characteristics of the specific commodity being extracted from the periphery and transferred to the core.

Though political ecologists have developed sophisticated instruments to quantify unequal ecological exchange, measured in terms of material and energy flows associated with historical core-periphery exchange, in the case of the Anaime watershed, the available data -both scarce and inconsistent- severely hampers any such approach. Nonetheless, evidence suggests that the Anaime Canyon's role as a provider for regional and national urban markets has upset the ecological relations of production in the valley, opening a metabolic rift and calling into question the long-term sustainability of Colombia's despensa agricola. Marx (1991 [1894]) employs the notion of the metabolic rift to describe the rupture in nutrient cycling in the soil provoked by the extraction of organic material from the countryside in the form of agricultural goods shipped to urban markets. In cities organic matter not cycled back to the soil accumulates in the form of sewage posing a waste management problem; while in the countryside the metabolic rift leads to soil exhaustion. For Marx, who based his analysis on Liebig's research into soil fertility, large-scale agriculture represented a form of exploitation of nature or a robbing of the soil [in which] all progress in increasing the fertility of the soil for a given time is a progress toward ruining the more lasting sources of that fertility (Marx, cited in Foster, 1999: 379). Owing much to Foster's (1999, 2000), ecological re-reading of Marx, the concept of the metabolic rift has come into wider use to describe the fundamental ecological contradiction of capitalist production at the heart of the antagonistic town/country, core/periphery relationships. As Moore (2003: 326) succinctly puts it, the metabolic rift is the ecological expression of value accumulation. For Wittman (2009: 808) the rift emerges from distancing and delocalisation as capital has restructured agriculture from a localized and diversified reproductive strategy into a highly productive, market oriented, and eventually globalized form of commodity production. Following Foster (2013), here the metabolic rift is understood as a more general theory of ecological crisis, describing not only the depletion of soil fertility brought on by capitalist agriculture, but the wider rupture with what Marx termed the universal metabolism of nature caused by the accelerated social metabolism of capitalist 
commodity production. As such, analysis of the metabolic rift in Anaime looks beyond the nutrient balance in the soil, and analyzes the more-general disruption in the local ecological relations of production brought on by market-oriented agro-food production, thereby including processes of soil erosion, deforestation, water pollution and reduced biodiversity that eventually loop back to condition production through complex agroecological cycles. In this sense, the metabolic rift opened by agriculture in Anaime results from ecologically unequal exchange in which environmental loads or costs are displaced from the core urban markets of Cali and Bogotá and forced upon the rural periphery.

While there is a healthy and growing body of work on environmental history in Colombia (Palacio et al., 2001; Palacio, 2006; Palacio \& Ruiz Soto, 2008; Leal, 2005; Van Ausdal, 2009, 2012; Gallini, 2015), no detailed work has yet been done on the Anaime Valley or upland agriculture in the department of Tolima. Cajamarca has recently been the subject of numerous works on the nature of eco-territorial conflicts sparked by the proposed mining project (Dietz, 2018; Jiménez, Doughman \& Montoya, 2017; Sánchez García, 2013), but none of these deal in depth with the transformation of the Anaime landscape prior to AngloGold's arrival in the early 2000s. The present research seeks to provide the backstory to present-day ecological conflicts in Anaime, by illustrating how nature has been appropriated and transformed historically in the valley, largely through agricultural production, to create the present landscape and a specific set of social, economic and cultural relations with the natural environment. The study draws on diverse sources to reconstruct Anaime's environmental history, including local and national archival records, census data and fieldwork, but also actively engages the local community in a retelling of its agrarian past ${ }^{1}$. In a workshop, over forty men and women from Anaime and Cajamarca recounted the changes that they had observed in farming techniques, the landscape, local ecosystems, diet and food production during their lifetimes. Thirty semi-structured interviews with campesino ${ }^{2}$ men and women and muleteers complemented this activity; thus, a rich, historical memory of agricultural development reaching back to the 1940s fills voids left by the patchy register of official statistics. The reconstruction of earlier history relies on correspondence related to the distribution of

1. The research relies heavily on qualitative data due to the paucity of reliable quantitative data on land use and agricultural production for the study area. Colombia has undertaken only three comprehensive agrarian censuses $(1960,1970,2014)$ and definitions for land use vary considerably from census to census. Studies in the Cauca River Valley (Marull, Delgadillo, Cattaneo \&, KrausMANN, 2018), suggest ways in which more detailed quantitative data on land use might obtained from aerial or satellite imagery in the future.

2. The term campesino is preferred to "peasant" or "farmer," to denote a culturally and historically specific class of rural smallholders in Colombia whose livelihood derives principally from agricultural production both for subsistence and for market. 
public lands in the valley at the end of the $19^{\text {th }}$ century and literary sources that provide sketches of the Anaime landscape in the decades following its colonization. Undergraduate agronomy and veterinary theses from the University of Tolima, provide data on crop diversity, production and market conditions in the years following Anaime's entry into the national food system at the middle of the $20^{\text {th }}$ century, providing limited quantitative data for the wide gaps between censuses.

Arguments are laid out as follows: a brief geographical description of the study area precedes an extended, chronological account of agro-food development in the AnaimeValley. This account has been divided into three periods, and in each, describes the valley's linkages to local, regional and national markets, as well as the ecological impacts brought on by changes in land use and agricultural technology. A separate section then analyzes Anaime's increased dependence on synthetic fertilizers and other off-farm inputs as well as changes in the nature of sharecropping agreements as evidence of the growing metabolic rift produced by long-distance food trade. The concluding section offers a brief reflection on the relevance of these findings and the potential of further participatory research to engage local campesinos in a continuing conversation on sustainability.

\section{THE ANAIME WATERSHED: FROM TROPICAL JUNGLE TO COLOMBIA'S GREENGROCER}

The municipality of Cajamarca in the Tolima department sits $37 \mathrm{~km}$ west of the department capital of Ibagué atop the eastern slopes of Colombia's Central Range. The Anaime watershed covers 28,586 hectares in the south of the municipality, over half of Cajamarca's total area of 51,564 hectares (Map 1). The village center of Anaime is located in the lower valley $6 \mathrm{~km}$ south of the municipal seat; further up the valley, El Cajón and Potosí are small settlements served by transit and convenience stores. Temperatures average $15.9^{\circ} \mathrm{C}$ and are constant throughout the year. Average annual rainfall is just over $1,000 \mathrm{~mm}$ and follows a bimodal pattern with the wettest seasons coming between April and June and between October and December. Higher elevations receive greater and more evenly distributed precipitation throughout the year. Elevations in the valley range from just below 1,800 meters above sea level at the confluence of the Anaime and Bermellón rivers to over 3,500 meters along the crest of the Central Range. The middle and lower slopes of the valley are steep, with $60 \%$ grades, but terrain grows gentler further upslope and up-valley. Soil profiles are deep, a product of layers of volcanic ash deposited in the region by successive eruptions of nearby Cerro Machín, and the more distant Tolima and Ruiz volcanoes. 
MAP 1

The Anaime watershed and its relation to regional and national markets in Colombia



Source: prepared by Jair Marroquin. 
Human occupation of the Central Range dates to the late Pleistocene, and archaeological research evidences discontinuous human settlement in the Anaime and Bermellón valleys prior to the arrival of the Spanish in the $16^{\text {th }}$ century, with cataclysmic volcanic eruptions forcing humans to abandon the area for centuries at a time. Settlement continued in the valley through the $17^{\text {th }}$ and $18^{\text {th }}$ centuries (Tovar, 1981) with the Anaima peoples cultivating maize in small clearings cut into a landscape dominated by the dense high Andean forest (Salgado \& Gómez García, 2000).

\subsection{Antioquian colonization and early market links, $1860-1940$}

Motivated by the promise of land amid high international coffee prices, the first mestizo settlers moved into the Anaime Canyon from Quindío in the mid- $19^{\text {th }}$ century, part of the Antioquian Colonization that spread southward along both flanks of Colombia's Central Range. While the lower Anaime Valley was suitable for coffee plantations, lands higher up were sown to corn for domestic consumption and livestock feed. This colonization was part of a general expansion of Colombia's agrarian frontier that would last into first decade of the $20^{\text {th }}$ century and leave the Central Range largely denuded of its dense native forests.

By the mid-1870s, enough colonists had settled in Anaime to petition for the concession of public lands. In 1879, the Congress of the United States of Colombia, granted 20,000 hectares to the inhabitants of Anaime, then part of the Ibagué District of the Sovereign State of Tolima ${ }^{3}$, and arrangements were made for the concession's survey ${ }^{4}$.

The 1881 report of Julio Liévano, the state-appointed surveyor, offers the first written description of the settled landscape in the Anaime valley ${ }^{5}$, and projects the optimism that accompanied the colonizing enterprise. He lauds the land's extraordinary vegetable wealth and the magnificent fields of maize and wheat established by the settlers, who by his account had been in the region for well over a decade. His report also shows considerable foresight, predicting that before long the valley will become a source of considerable wealth developed through agriculture and a granary for the center of the country. Yet Liévano worries that

3. The process for adjudicating public lands is set out in Law 14 of April 21 of 1870. An Agrarian Commission made up of local farmers would assign public lands to male settlers, allowing for 32 hectares for men without children and an additional 5 hectares for every child under 21 years old in the man's care. Further dispositions prohibited the future sale or transfer of lands to other landholders who already possessed over 50 hectares in the area.

4. Archivo General de la Nación (AGN), fondo Baldíos, legajo 3; folios 355-357. "Los habitantes de Fresno y Anaime se responsabilizan de la mensura de los terrenos”, 1880.

5. AGN, fondo Baldíos, legajo 3, folios 230-248. “Terrenos baldíos en Fresno y Anaime”, 1881. 
its location -a full-day's-ride from Ibagué over steep terrain and treacherous rivers- might fetter trade. Later, when wheat crops have gained sufficient proportions to provide for all of central Tolima and even for a few towns in Cauca, this point [Anaime], for lack of roads, would be too remote to serve as a center for the transactions created by its agricultural development.

Liévano's report and the string of correspondence between colonists in Anaime and the Secretary of the Treasury regarding land rights reveal the same contradictions that fraught land distribution in Colombia as a whole. Although laws with an egalitarian spirit sought to limit the private accumulation of public lands, ministry officials often granted immense tracts of the best lands to holders of land bonds issued to cover Colombia's ballooning foreign debt (Machado, 1986). In Anaime, the law entitled settlers to lots not exceeding 50 hectares, while bondholders petitioned for holdings upward of 750 hectares in the valley ${ }^{6}$. Liévano worried openly about the number of deedless settlers and false deeds already circulating at the time of his visit. The limited archival record paints a picture of overlapping claims and contested interpretations of the rights accorded to cultivators who occupied and improved the land without legal title ${ }^{7}$. Eventually, landed interests won out; by the beginning of the $20^{\text {th }}$ century, a number of large haciendas raising cattle occupied the better part of the valley. Smallholders continued to cultivate corn, coffee, beans and legumes on the crowded slopes of the lower valley.

Some twenty years after Liévano's visit, the Liberal general and politician Rafael Uribe Uribe described Anaime in terms that echoed the surveyor's, calling it a thing of giants [...] for the enormous dimension of the agricultural labors undertaken by its inhabitants (Uribe Uribe, cited in Pava, 2002: 18-9). He too praised the industry of the Antioquian colonists who had built their own roads and bridges and were already clearing the slopes in the highest valleys and grazing cattle in the páramos.

[Anaime] provides its fruit to Ibagué and other populations... and uses maize from its granaries, product of its vast fields, to fatten hogs, sending 7000 of them a year to all parts of Tolima, La Mesa, Cundinamarca, and Antioquia; as its woods have rotted and the land has been tamed, pastures have been formed and they breed cattle there and export cheese without having abandoned altogether raising hogs (Uribe Uribe, cited in Pava, 2002: 18-9).

Thus, Anaime already formed a marginal part of Ibagué's food system, and sent highervalue cheese and hogs across the Magdalena to Cundinamarca or downriver to Antioquia.

6. AGN, fondo Baldíos, legajo 7, folios 66-8.

7. Law 61 of 1874 guaranteed property rights to those who farmed uncultivated government lands. 
Uribe also notes the trend in which open-range grazing began to replace the relatively confined hog-raising operations of Antioquian campesinos that had initially driven the local economy. While impressed by Anaime's prosperity, Uribe too condemns the state of the long, hard, twisted, tiring and ridiculous road to Ibagué, that hindered an otherwise bounteous agricultural trade.

Its population nearing $4,000^{8}$, Anaime became a separate municipality in 1908 , despite the objections of a minority of politically-connected, absentee landholders who feared an administrative break with the department capital would lower property values ${ }^{9}$. Nonetheless, topography conspired against Anaime's existence as a municipal seat; the small meadow wedged between the valley walls at Las Hormas was too narrow to hold the village's growing population, forcing local leaders to found San Miguel de Perdomo, now Cajamarca, on the Old Ibagué plane ${ }^{10}$. Here, the small mesa allowed for enough growth that San Miguel eventually displaced Anaime as the municipal seat.

In the early $20^{\text {th }}$ century, coffee production at the lower elevations forged an early link between the Anaime Valley and the international market, and provided an economic mooring for smallholder agriculture in the lower valley as large, livestock holdings covered the upper valley. By this time, smallholder coffee production in the Central Range associated with the Antioquian colonization had eclipsed the traditional coffee plantations in Santander and Cundinamarca and keyed the consolidation of Colombia's coffee-based agroexport economy (Ocampo, 2015). Notwithstanding, coffee plantations in Anaime were limited to lower elevations along the river and nearest its confluence with the Bermellón. Beyond this, subsistance agriculture sought mainly to feed family and livestock, while selling surpluses locally. Agricultural techniques reflected the relative shortage of labor power, most of which was provided by family members and was likely directed toward land clearance, which not only allowed for expanded production but constituted capital improvement. Locals describe maize and beans as the main crops, though wheat and barley persisted on the middle and upper slopes. Often, seeds were broadcast directly onto the untilled earth after a parcel was cleared. Pigeon peas (Cajanus cajan), were common, as they were hardy and required no trellis.

8. AGN, fondo Baldíos, legajo 36, folio 292. "Solicitud de julio 20 de 1912 para concesión de baldíos para el área del poblado de Anaime".

9. Biblioteca Nacional de Colombia, encuadernado MP1-3.

10. The plane had been the site of Ibagués original founding in 1539, but hostility from the Pijao's and a lack of nearby drinking water forced Andrés López de Galarza to abandon the plane and refound Ibagué at its present site after a few months. 
Simón de la Pava's (1991) auto-biographical novel, Este es mi testimonio, describes the changing landscape of the upper watershed in the 1920s and 1930s. Rife with images of the masculine dominance of nature, the novel captures the spirit of the Antioquian colonization, and describes how a few families amassed extensive holdings in the highlands. He recalls the valley as an immense womb of lands cleared by men's greed (Pava, 1991:290) and paints the felling of the forests in terms of epic warfare: that battle with no other weapon than a hatchet, a saw and a hoe (ibid.: 322). In his narrative, camps of men worked continually to convert large swaths of this Andean forest to pasture often planting a crop of potatoes first to "tame" the soil.

The novel catalogs Anaime's diverse wildlife in detail even as it was being exterminated by the expansion of pasturelands. Páramos were still crowded with frailejones, while mountain tapirs, spectacled bears, and red brocket roamed the forests along with innumerable species of birds. The cloud forest was thick with cedars, guarumos, laureles, chaquiros and encenillos out of whose dense stands rose wax palms.

Despite pressure on a national scale to expand food production, Anaime remained isolated in a regional economy, with surpluses being directed to Ibagué or Armenia. Incipient industrialization in the early 1900s had spurred urbanization and increased the cities's demand for food (Ocampo, 2015), while inflation driven by the coffee boom and food shortages in the 1920s, fueled the push for greater production of staple crops like wheat, corn, potatoes, beans and cocoa (Kalmanovitz \& López Enciso, 2006). Anaime's remote location had limited its participation in any nascent national market, but by the mid-1930s, the road between Ibagué and Armenia had been improved to accommodate automobile traffic. Trucks passing between Bogotá and Cali and the Pacific motored through the center of Cajamarca. By the early 1940s, trucks entered the Anaime Valley as far up as the village, though land further up remained the domain of oxen, horses and mules. Infrastructure improvements would soon aid not only the growing flow of produce issuing from the Anaime Valley, but also the arrival of laborers from Cundinamarca and Boyacá, largely responsible for the coming agricultural boom.

\subsection{Immigration and an agricultural boom, $1940-80$}

A series of reforms undertaken in the 1930s and early 1940s had primed Colombia for further industrialization from the mid-1940s onward. Operating with a new interventionist bent, the Colombian state placed limits on the import of finished goods and created the Industrial Foment Institute to promote national production. The Bank of the Republic, created in 1931, opened new lines of credit. Cali, Medellín, Bogotá and Barranquilla 
emerged as powerful centers in a regionally specialized national industry, and rapid urbanization was already underway by the mid-1940s. Growing urban markets and the imperative to lower food prices as a check on worker wages prompted a geographical expansion of the cities's provisioning systems. At mid- $20^{\text {th }}$ century, the volcanic soils of the Anaime Valley, heretofore linked mainly to regional markets in Ibagué and Armenia, were now called upon to produce for urban centers in Bogotá and Valle de Cauca.

Geologist and engineer Otto Pichelmayr's report ${ }^{11}$ appended to an 1943 application for a mining title in the Cucuana drainage in the upper watershed offers a glimpse of the valley just prior to the agricultural boom. Pichelmayr describes a picturesque valley boasting abundant crops and cattle, but transportation remained a limiting factor. By his estimates, the cost of packing a ton of ore by mule down to Anaime stood at $\$ 9.60$ pesos; trucking the same ton to Ibagué cost another $\$ 7.00$ pesos, and from there onto Bogotá by train another $\$ 7.50$ pesos.

Pichelmayr's report suggests that land clearance in the upper watershed had advanced, but was far from complete. He describes the solicited 1,300 hectare plot as being $75 \%$ forested, with $15 \%$ under pasture and the remaining land planted to potatoes and wheat. Photographs of the upper watershed show lush forests ribboned by cascading streams, but also clearcut hillsides and felled trunks littering expanses of planted grass (Images 1 and 2).

By the late 1930s and early 1940s, immigrants began to arrive from the highlands of Cundinamarca and Boyacá, attracted by higher wages and the relative availability of land ${ }^{12}$. Cajamarca's population rose from 13,384 in 1938 to 18,943 in 1951, with the large majority $(14,303)$ living outside the municipal seat (DANE, 1942, 1954). Immigrants brought new cultivars and farming techniques, as well as experience in commercial agricultural production. Some brought enough capital to buy land outright, while others leased land to farm, investing proceeds in its eventual purchase. The majority accessed land as aparceros $^{13}$ on larger holdings or worked as paid laborers. For local landowners, the in-

11. AGN, fondo Minas y energía, unidad de conservación 51, folios 131-61. "Propuesta de mina en la Floresta, zona Mirasol". See supplementary images in the appendix: DOI https://doi.org/ 10.26882/histagrar.080x03d

12. Many locals speculate that political turmoil in Boyacá and Cundinamarca associated with La Violencia was a driver for immigrants coming to Anaime, but in the survey done by VILLAREAL and ARIAS (1970), none of those who had come to the valley from other regions cited public unrest as the cause of migration.

13. Aparceria is a type of sharecropping agreement in which one party, the aparcero, leases land from the property owner, and rent is paid as a percentage of the proceeds from the crop's sale. See 
flux of workers eased the chronic labor shortage, and allowed them to exploit their lands more intensively. The staples of maize, beans, potatoes, and wheat continued to thrive, but now grew alongside patches of arracacha, cabbage, beets, peas, carrots and squash.

IMAGES 1 AND 2

Native forests cleared for pasture on the slopes of the Cucuana Drainage of the Upper Anaime, 1943
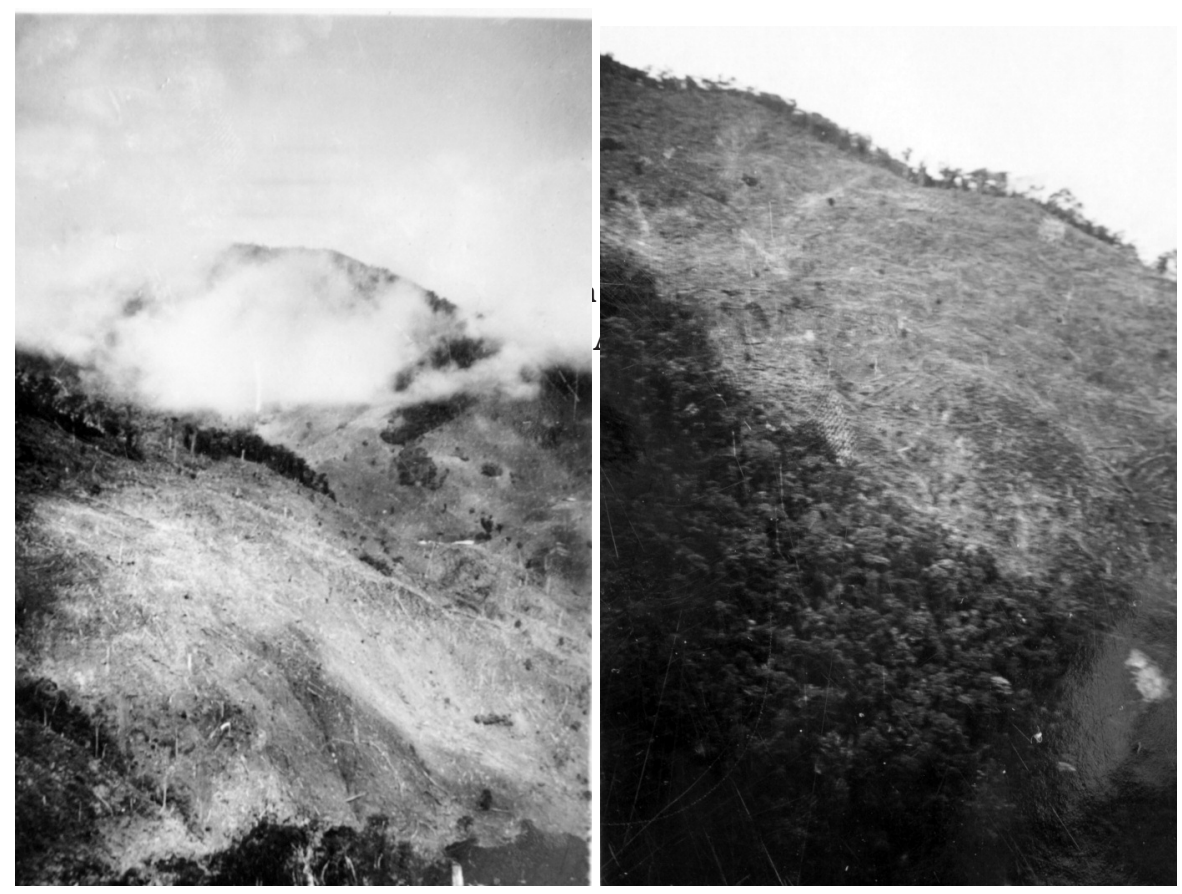

Source: AGN, fondo Minas y energía, unidad de conservación 51, folios 131-61. "Propuesta de mina en la Floresta, zona Mirasol”. Digitized by Mauricio Clavijo.

Smallholder agriculture cut away at the larger cattle operations, as the original estates were parceled off, leased, sharecropped or bought outright by the arriving campesinos. Changes in land use also changed the local ecology. In the Judea, Hormas, Arenillal and Águila veredas ${ }^{14}$ cultivated fields expanded at the expense of the remaining stands of trees, leaving only thin strands lining ridges and drainages and pushing wildlife out of the lower valley. The widespread use of heavy hoes by the Cundiboyasenses increased soil tillage, hastening the erosion of the thick soils on the steep slopes of the valley.

GutiÉRREZ MALAXECHEBARRía (2011) for an analysis of aparceria in the Anaime Valley.

14. In Colombia, vereda, refers to a rural administrative subdivision within a municipality. 
Agricultural intensification in the Anaime Valley continued into the 1950s as infrastructure projects tied the Anaime Canyon more closely to the regional centers of Ibagué and Armenia and national markets in Cali and Bogotá. An improved dirt road running between Anaime and Potosí replaced the mucky cart trail along the river in 1954 and effectively opened the canyon to motor vehicles. The immense, steel bridge spanning the Anaime River on the Ibagué-Armenia road was finished in 1959 as part of a broader infrastructure initiative undertaken by the Colombian government and financed in part by the International Bank for Reconstruction and Development.

New roads not only supplied urban markets, but conducted Colombia's fast-growing population out of the countryside and into the city, part of a furious process of urbanization in the mid- $20^{\text {th }}$ century. The population of Colombia's cities exploded as waves of campesinos fled LaViolencia, the partisan conflict that ravaged the Colombian countryside following the 1948 assassination of liberal firebrand and presidential candidate Jorge Eliécer Gaitán. Ibagué and Armenia grew by $60.6 \%$ and $54.2 \%$ respectively between 1938 and 1954, and again by $65.8 \%$ and $75.1 \%$ by 1964 (Table 1). Bogotá was five times larger in 1964 than it had been in 1938; Cali, another major market for Cajamarca's produce, had grown by a factor of over six in the same period (DANE, 1954, 1967).

\section{TABLE 1}

Population of Cajamarca and its principal markets, 1938-73

\begin{tabular}{lccrr}
\hline Municipality & $\mathbf{1 9 3 8}$ & $\mathbf{1 9 5 1}$ & $\mathbf{1 9 6 4}$ & $\mathbf{1 9 7 3}$ \\
\hline Cajamarca & 13,384 & 18,943 & 16,947 & 15,867 \\
Ibagué & 61,447 & 98,695 & 163,661 & 208,699 \\
Armenia & 50,838 & 78,380 & 137,222 & 145,341 \\
Bogotá & 330,312 & 648,324 & $1,697,311$ & $2,571,548$ \\
Cali & 101,083 & 284,186 & 637,929 & 918,057 \\
\hline
\end{tabular}

Source: DANE (1942, 1954, 1967, 1978, 1994, 2018).

As the Conservative paramilitaries known as Chulavitas and the Liberal guerrilla alternately pillaged family farms, 722 cajamarcans died by violence between 1945 and 1966 $\left(\right.$ Marín, 2013) ${ }^{15}$. Between 1951 and 1964, bloodshed drove 3,544 persons out of Cajamarca's rural areas, and total population dropped by over 10\% (DANE, 1954, 1967). Political violence also reshaped the Anaime landscape; as families in the uplands sought

15. Memories of LaViolencia run strong in the older generations. Many recall details of where they were when news of Gaitán's assassination came over the radio; others recall sleeping in the woods at night to hide from the Chulavitas. Stories abound of neighbor's being shot or having their throats slashed, of children being executed and corpses being displayed publicly or thrown into the river. 
refuge down-valley, population concentrated in the densely-farmed lower reaches. Opportunistic landholders, often residing safely in Ibagué, appropriated abandoned lands and livestock, solidifying the hold of large property on the upper Anaime.

Looking to feed its cities, Colombia invested in agricultural modernization in the 1950s, expanding credit through the Farm Credit Bureau (Caja Agraria) and subsidizing mechanized rice and cotton in Tolima's lowlands along the Magdalena River, but smallholder production on the slopes of the Central Range lay outside the scope of state investment and Green Revolution technologies. Instead, Anaime's agricultural bounty grew from the natural fertility of the soils. Locals recall sowing directly in the thick humus exposed after forest clearance and cultivating without fertilizers, insecticides or herbicides. The 1960 Agrarian Census (DANE, 1964) bears out their accounts as only $1 \%$ of the plots surveyed reported using synthetic fertilizers. Campesinos made ample use of intercropping and crop rotations, growing arracacha, beans and maize in association. Beets, cilantro, carrots and cabbage were grown together as were potatoes, peas and beans (García \& Cortés, 1973). Maize, beans and arracacha occupied the largest areas, while wheat and barley had all but disappeared (Table 2). Coffee and plantain production, though present in the lower valley, was concentrated in the Coello Valley between Cajamarca and Ibagué.

TABLE 2

Agricultural production in Cajamarca, 1960

\begin{tabular}{lcc}
\hline Crop & Number of plots & Harvested area (Ha) \\
\hline Arracacha & 640 & $1,200.6$ \\
Peas & 161 & 199 \\
Sugarcane & 35 & 81.9 \\
Onion & 143 & 291.8 \\
Barley & 2 & 2 \\
Beans & 492 & $1,157.2$ \\
Maize & 1,009 & $2,250.6$ \\
Potato & 104 & 120 \\
Cassava & 104 & 103.7 \\
\hline \multicolumn{3}{c}{ Bananas/Plantains } \\
Coffee & 528 & $1,219.1$ \\
\hline
\end{tabular}

Source: DANE (1964).

For agricultural lots, the dominant form of land tenure in the 1950s was aparceria, a sharecropping agreement in which landowners provided land, rations for workers and split the costs of seed and tools with the aparcero, who provided labor. Proceeds from the crop's 
sale were divided evenly between the two parties. Over $44 \%$ of the rural plots in Cajamarca, some 5,700 hectares, were worked under aparcería agreements in 1960 (DANE, 1964). Aparcería provided a means for landless immigrants to access land, and while landholders used it to fix labor and more profitably exploit their lands.

Anaime consolidated its reputation as the Colombia's greengrocer in the 1960s as agriculture expanded in the lower valley, infrastructure made markets more accessible and chemical inputs came into wider use. By the end of the decade, the road between Cajamarca and Anaime had been paved, and improvements had begun on the canyon road. Local cooperatives offered regular jeep service up to Potosi ${ }^{16}$, and ten-ton trucks now picked up produce along the road for delivery to urban markets, further integrating the Anaime Valley into the regional and national food systems.

Over 9,000 hectares of land in Cajamarca were brought into new use during the decade. Cultivated lands jumped from 5,396 to 7,157 hectares, while pastures grew from 22,023 to 26,666 hectares. Land ownership displaced aparceria as the predominant form of tenure as formerly landless laborers and aparceros bought land of their own, cementing the smallholder landscape that still characterizes Anaime's lower veredas (DANE, 1974). Meanwhile, larger holdings in the upper valleys were merged and bought by a handful of wealthy families ${ }^{17}$.

A study by Villareal and Arias (1970) renders a cross section of agricultural production in the valley at the time. Of 82 plots surveyed, 54 were agricultural, 11 were exclusively livestock operations and the remaining 17 were of mixed use. Nearly two-thirds of the plots had an acreage below 20 hectares and a full third were under 5 hectares. Arracacha, maize and potato covered nearly $75 \%$ of the cultivated area, with remaining lands planted to beets, carrots, cabbage, beans, peas and onion. Increasingly, campesinos farmed with the aid of Green Revolution technologies, influenced, perhaps, by agricultural modernization underway in the Magdalena Valley and pressed by labor scarcity following the rural exodus of LaViolencia. The valley's steep terrain prohibited mechanization, but locals recall chemical fertilizers and backpack sprayers filled with parathion and malathion replacing older practices of soil management and pest control. Villareal and Arias (1970) found that 70 out of 71 campesinos used insecticides, while 48 used chemicals on their crops to control disease; well over half used synthetic fertilizers in some form.

16. AGN, fondo INAT. “Contrato de Construcción Carretera: Anaime, La Floresta, Santa Helena. 1967-1968".

17. Joaquín Quintero, a noted landholder haling from Boyacá, came to own a half-dozen properties and several thousands of acres in the upper watershed. 
Yet, this technological transfer occurred largely outside the purview of state initiatives. The vast majority sourced seeds and propagules from their own lots or from neighbors, while only two persons surveyed had received seeds from public entities. None of the cultivators interviewed had received technical assistance of any kind, and credit from the Caja Agraria flowed more readily to dairy production than to agriculture.

In the upper valleys, the dual-purpose cattle herd expanded, balancing dairy and beef production. Breeding programs were in full swing, but dairymen spurned lighter breeds like Guernseys and Ayrshires, more appropriate for the high altitude and steep terrain, in favor of Normandes, whose steers could be fattened more gainfully. Every day anywhere from 6,000-6,750 liters of milk were delivered to Armenia; another 900 liters were consumed locally, and 2,250 liters more were made into cheese, but there were already signs of lagging productivity. Years of grazing had increased soil alkalinity and brought on calcium and phosphorus deficiencies (Fonseca \& Bernal, 1969).

Indeed, locals identify the 1960s as an important moment of ecological change in the valley. Victims of both hunting and habitat destruction, deer, puma, mountain tapirs and the spectacled bear had vanished from the highlands as kikuyo, meadow grass and burclover had replaced the cloud forests on all but the steepest slopes. Incipient reforestation efforts planted fast-growing eucalyptus and pine rather than restore the Andean forest ecosystem. Hummingbirds, wasps and bees, all important for pollination, dwindled at lower elevations as wild, flowering plants disappeared and insecticide use increased. Soil conservation techniques remained limited; crops were often sown along on the slope, rather than contoured; cover crops were seldom used, and weed control was done with heavy hoes. Heavier tillage and the continued deforestation of drainages contributed to soil erosion (Villareal \& Arias, 1970); less water flowed in the streams feeding the Anaime River, and concrete contention walls had to be built in the village to control floods caused by sedimentation.

The 1970s saw a general increase in public investment in agriculture, including programs aiming to improve productivity in Colombia's smallholder sector. Research and agricultural extension from the University of Tolima arrived in Anaime as did the state geography office, which commissioned soil studies across the region and mapped erosion and vegetation cover in the Coello watershed. Thus, agricultural intensification in the valley, begun autonomously, was now at least partially guided by state-funded research and technology transfer.

Modernization meant increased specialization; arracacha, the most profitable cultivar, spread over Anaime's hillsides. Beans fell out of their association with arracacha and maize 
as campesinos adapted more marketable varieties like cargamanto and bola roja that required trellises. Improved varieties of potato and corn arrived as well, certified by the Colombian Agricultural Institute (ICA). As crop rotations simplified or were replaced by monoculture, new pests and diseases appeared. Cutworms (Agrotis $s p$ ) affected the potato, cabbage and carrot crops. The chisa (Melolonthinae) larva ate through the arracacha patches. With new pests, came an increased use of insecticides, often applied indiscriminately based on the advice of local retailers.

Agriculture in Anaime became more capital intensive and dependent on credit flowing through the Caja Agraria. The private sector too stepped in, and the Bank of Colombia opened a branch in Anaime. Loans were often tied to technological packages including certified seeds and technical assistance (García \& Cortés, 1973). Thus, access to credit, in turn, spurred the modernization of agricultural practices in a mutually reinforcing cycle that deepened campesino dependence both on credit and on synthetic inputs.

\section{TABLE 3}

Produce trade and principle markets of crops in Anaime, 1980

\begin{tabular}{lcr}
\hline Crop & Volume shipped to market (Tons) & Principle markets \\
\hline Arracacha & $13,678.5$ & Bogotá, Cali, Armenia, Ibagué \\
Peas & 582.7 & Cali, Armenia, Ibagué \\
Beets & $1,244.6$ & Cali, Armenia, Ibagué \\
Carrots & 716.3 & Cali, Armenia, Ibagué \\
Beans & 507 & Cali, Armenia, Ibagué \\
Potatoes & 420 & Armenia, Ibagué, Cajamarca \\
Tomate del árbol & 62.5 & Ibagué, Cajamarca \\
\hline
\end{tabular}

Sources: Mondragón and Motta (1980).

Production was overwhelmingly commercial; only maize and potatoes were consumed locally in any quantity. During harvest months, Anaime dispatched 790 tons a week of produce to Colombia's urban markets. Bogotá received 350 tons of arracacha, Ibagué received 165 tons, mainly of cabbage and beets; Armenia, 135 tons of onions, tomatoes, peas and arracacha; Cali, 108 tons of peas, cabbage, beets, cucumbers and beans, and three truckloads a week carried 21 tons of carrots, beets and arracacha to Barranquilla on the Atlantic Coast ${ }^{18}$ (García \& Cortés, 1973). By the decade's end, 3,763 hectares were under cultivation in the Anaime Valley alone, with arracacha-intercropped with maize- occupying roughly half of the cultivated land. Smallholder agriculture in Anaime produced

18. Calculations are based on the registry of produce transported between 1971 and 1973 by the Transquindio and Centrolima Transport Company. 
roughly 17,226 tons of produce for market, including 13,687 tons of arracacha, nearly $80 \%$ of which went to Bogotá (Table 3) (Mondragón \& Motta, 1980).

\section{IMAGE 3}

Landslides signal erosion caused by overgrazing in the Anaime Valley in the early 1970s

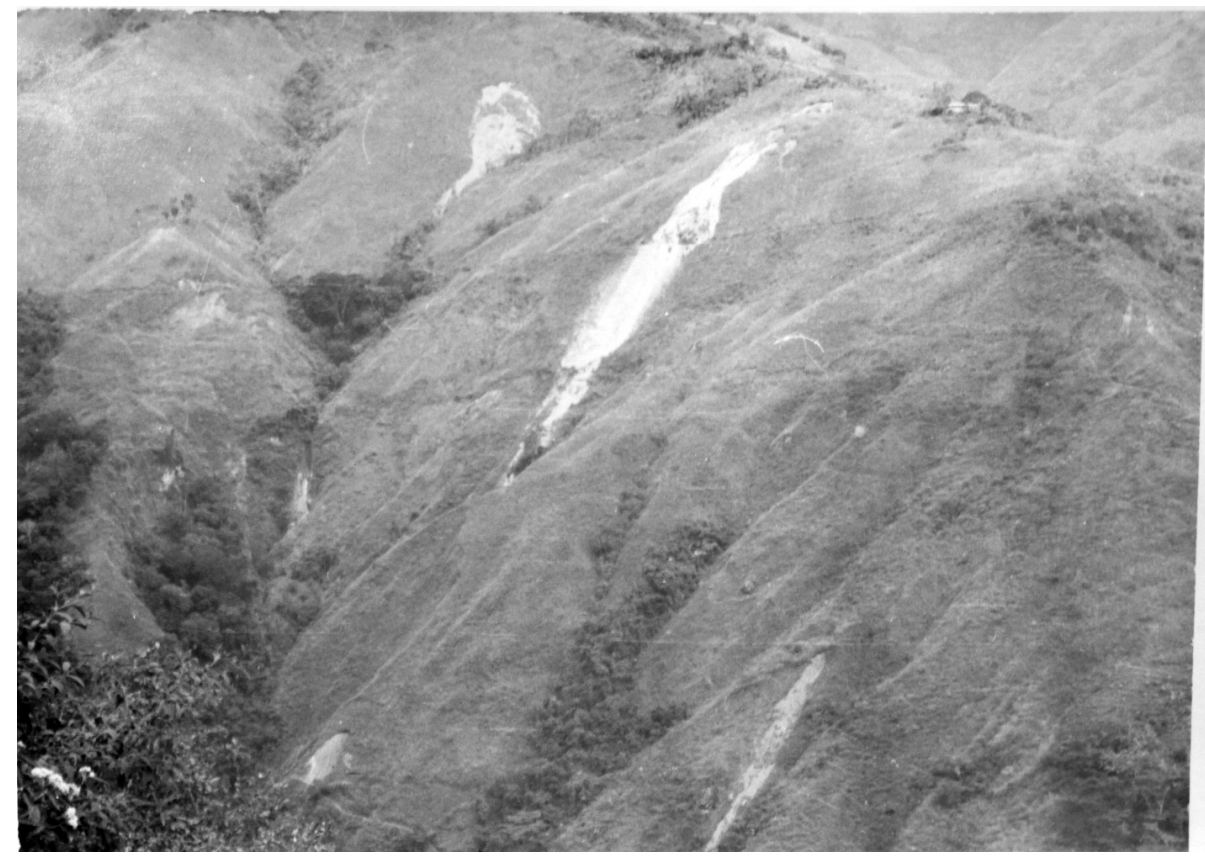

Source: Jesús A. Jordán in Rodríguez et al. (1974). Digitized by Nicolás Melgar.

Yet two decades of intensified land use had taken a toll on local ecosystems. A 1974 soil study recognized the volcanic soil's general aptitude for agriculture, but noted the absence of soil conservation practices and an overall need for technical assistance (IGAC, 1974). A 1976 study on erosion and vegetation in the Coello watershed was more condemning. It found primary forests to be extinct on all but the steepest and wettest slopes of the watershed, including the AnaimeValley, and thinned stands of secondary forest clinging only to ridgelines and drainages. Slumping, soil creep and landslides evinced severe erosion where steep slopes had been overgrazed in highland pastures (Image 3). Cultivated slopes between 1,800 and 2,400 meters above sea level showed signs of intense erosion due to surface runoff and mass movements. The report specifically identified the Anaime watershed as a significant contributor to the overall sedimentation of the Coello river (IGAC, 1976). According to locals, continued deforestation at the time reduced the flow of streams and drainages. Native species of fish, like the guilo disappeared from the Anaime 
River, later to be replaced by introduced trout. The remaining stands of trees were home to fewer birds and mammals. Populations of emblematic species like the oriole blackbird, the Colombian chachalaca, the yellow-backed oriole, and the emerald toucanet continued to decline, likely victims of increased pesticide use.

\subsection{Specialization, conservation and internationalization, 1980-Present}

During the late 1970s and the 1980s, violence subsided in the Cajamarca countryside, and the rural population -those living outside the municipal seat and Anaime's village center- rebounded, reaching 10,825 by 1993, an 18\% increase from 1973 (DANE, 1994). Greater population increased pressure on the land, and though the basic structure of land tenure held, the mosaic of smallholder agriculture tightened as family lots in the lower valley were divided among heirs. In the upper valley, too, many of the largest properties were broken up; the number of 1,000-2,000 hectare plots dropped from eight to three between 1971 and 1989 (URPA, 1989). One property, Potosí, was fractioned off as part of a limited agrarian reform effort in the valley led by Colombia's Rural Reform Institute (INCORA). Its 1,900 hectares were purchased from the cattleman's association and divided among some sixty families, a number of them squeezed out of the lower valley and looking for access to land upvalley ${ }^{19}$.

Behind smallholder arracacha and bean production, Cajamarca continued to play the role of despensa agrícola. According to Tolima's development secretary, in 1989 some 7,400 hectares in Cajamarca were planted to seasonal crops including arracacha, beans, beets and cabbage, a 54\% increase from 1970. Permanent crops such as coffee and plantains had receded sharply, covering a mere 770 hectares in 1989 compared to 3,301 hectares in 1970. The dual-purpose cattle herd had grown to an historic high of 21,593 head, up from 18,330 in 1970; pastures covered nearly 30,000 hectares, a $12 \%$ increase from two decades earlier. Natural forests had been reduced to 6,259 hectares, and secondary forests covered another 3,354 hectares. An estimated $10 \%$ of municipality's land was used beyond its capacity (URPA, 1989). During the 1980s, arracacha monoculture fully replaced the older arracacha-maize association. Both fertilizer and pesticide applications increased. In the latter case, excessive pesticide use contributed to genetic resistance to the organophosphorus compounds among chisas, leading the Colombian Cor-

19. Thirty years later, the results of the Potosí land reform are limited. Nearly two-thirds of the families abandoned the project in its early stages, but by dint of political organization, the remaining families obtained funding for a health-care post as well as a bulldozer to keep the road open. More families were displaced by guerrilla and later paramilitary violence in the 1990s the early 2000s, and their fractions were bought by those families that stayed, leading to re-concentration. 
poration for Agricultural Research (Corpoica), the semi-privatized offspring of the ICA, to research the problem in the early $1990 \mathrm{~s}^{20}$ (Corpoica, 1994).

With nearly 1,850 hectares planted to arracacha and yields well above the national average (Corpoica, 1994), Cajamarca accounted for as much as $60 \%$ of the Tolima department's production at the beginning of the 1990s and as much as a third of Colombia's annual crop. Nationwide arracacha production expanded throughout the decade reaching an historic high in 2001 with a harvested area of 8,768 hectares. Tolima alone harvested a record 5,202 hectares in 1999 (Ministerio de Agricultura, 2018), and at times was the sole provider to the Bogotá market (Corabastos, 1996). Though estimates for the cultivated area of arracacha in Cajamarca run as high as 5,000 hectares (Vásquez Acosta \& Gutiérrez, 2000), even at the historic peak of production in the late 1990s, acreage is unlikely to have crept above 4,000 hectares ${ }^{21}$. Yet, arracacha defined the geography of Anaime's economy, concentrating both resources and population in the most productive veredas in the lower valley (Vásquez Acosta \& Norato, 2000), while larger producers operated in the veredas La Leona, and La Despunta further up the valley (Arce et al., 2000).

Bean production, historically secondary to the arracacha, expanded throughout the 1990s and 2000s, as national production shifted south from traditional centers in Antioquia and Boyacá into Tolima and Huila. Tolima's cultivated acreage grew over four fold between 1987 and the year 2000, while its participation in national production rose over five fold (Ministerio de Agricultura, 2018). Buoyed by sustained, high prices between 2001 and 2009, bean cultivation rivaled and occasionally surpassed arracacha production in terms of planted area, as Cajamarca supplied markets in Medellín, Cali, Ibagué and Bogotá (Ministerio de Agricultura, 2018), but increased production put renewed pressure on forest resources as campesinos cut trees to erect trellises.

If arracacha and beans remained fixtures on Anaime's steep slopes, the surrounding crops began to change. Trade liberalization in the 1990s brought a new push for specialized fruit production as Anaime looked to foreign markets for the first time in crops other than coffee. An assortment of passiflora (cholupa, gulupa, granadilla) as well as tomate de árbol and lulo steadily replaced the beets, carrots and cabbages that had been cultivated for decades. Maize, the staple of the campesino diet, a feed source for hogs and chickens,

20. Public funding for the ICA was slashed beginning in the 1980s: reflecting a worldwide trend in shrinking pubic investment in agriculture and agricultural research (KALMANOVITZ \& LÓPEZ ENCISO, 2006).

21. The difference between harvested and cultivated area varies widely from year to year. Depending on climate and pests, losses can be significant. In recent years, the MINISTERIO DE AGRICULTURA (2018) has reported losses of over $20 \%$ in Cajamarca due to crop damage. 
and longtime partner of the arracacha in intercropped systems, steadily disappeared from the Anaime landscape as cheap grains became available on the market and large-scale livestock operations in Antioquia undercut local pork production.

Much of the agricultural expansion of the 1990s took place under guerrilla occupation. Liberal guerrillas and later the Revolutionary Armed Forces of Colombia-People's Army (FARC-EP), had roamed the páramos and wooded highlands since the 1950s, but in the mid-1990s, the guerrilla advanced down the valley, seizing the village in 1996. Occupation lasted into the new millennium, when, under President Álvaro Uribe Vélez, military and paramilitary forces entered to reclaim the region. Agricultural production in the lower valley continued unabated despite arbitrary executions by the guerrilla and later massacres perpetrated by state and paramilitaries forces. However, in the upper valley, violence harried livestock operations and displaced families to the municipal seat in Cajamarca, Ibagué and other cities. After over a century of expansion in the upper Anaime, dairy operations contracted in the absence of investment; landowners, often victims of extortion, dared not visit their herds and instead entrusted them to administrators. Paradoxically, the guerrilla's presence had a regenerative effect on highland ecosystems. Hunting and fishing in the valley were strictly forbidden, as was the felling of timber. Amid the violence, the forest encroached on pastures; wooded swathes linking adjacent watersheds along the spine of the Central Range formed strategic corridors for covert guerrilla movement between municipalities and became de facto conservation areas.

Even after the guerrilla's withdrawal in the early 2000s, conservation and reforestation efforts have continued in the upper Anaime, aided by the stagnation of the dairy sector, whose profits have been pinched by rising production costs and increased competition under new free trade agreements (FEDEGAN, 2014). Institutional backing has also played an important role. In the late 1990s, local cattleman, Joaquín Quintero donated more than 1,000 hectares at the edge of the páramo as a nature reserve. Looking to assure their future water supply, rice-growers of the Coello River irrigation district (USOCOELLO) in Espinal, bought a large tract in the Cucuana drainage for conservation. CORTOLIMA, the departmental environmental regulation agency, procured a neighboring property to the same end. More recently, in 2009, another 300 hectares on the opposite slope were converted to a private wildlife preserve harboring five species of Andean parrots among dozens of other species dependent on the páramos and the high Andean forest. In 2017, CORTOLIMA patched together these separate efforts, setting aside a total of nearly 13,000 hectares in the Anaime-Chili páramos as a Regional Natural Park protected from grazing and the more recent threat of mining. 
After nearly two decades of de facto and de jure protection, colonizing species of the montane forest like the siete cueros (Tibouchina lepidota) have taken root in abandoned pastures, and thickets advance along the forest edge. The 2014 rural census registered an optimistic 22,006 hectares of natural forest in Cajamarca and a mere 7,173 hectares of pasture. The 2012 municipal development plan more realistically estimates some 19,000 hectares of forest and 15,406 hectares of pasture (Alcaldía Municipal de Cajamarca, 2012). Nevertheless the figures from both sources manifest the secular reduction in Cajamarca's dual-purpose cattle herd which dropped to 17,326 head in 2016, down $20 \%$ from 1989 (URPA, 1989; DANE, 2016) ${ }^{22}$.

Today, a panorama of the valley seen from the road above Potosí shows the fringes of secondary forest pushing back against the large dairies in the upper valley. The tight patchwork of small-holder plots in the middle and lower valley, dense with the yellow-green rows of arracacha and trellises of peas and beans, creeps imperceptibly upward as local temperatures have risen as a result of climate change; further down, the dark green coffee plantations cling to the steepest slopes along the river. New to the agricultural landscape is the plastic sheeting of greenhouses built for tomato and passiflora cultivation, as are the open ranks of young avocado trees in the lower valley.

Official data offer a more precise rendering of agricultural landscape. The 2014 rural census found 9,435 hectares under agricultural use, with 8,816 hectares cropped to seasonal or permanent cultivars (DANE, 2016). Data from the municipal extension service reflects the rise in tomato, passiflora and avocado cultivation, the latter a product, in part, of AngloGold Ashanti's corporate responsibility program promoting Hass avocados for export (Table 4). Invariably erected on credit, the greenhouses and the avocado plantations, evidence novel forms in which finance capital flows through Anaime's agriculture. In contrast to decades past, a mere 65 hectares were planted to maize in 2018 (UMATA, 2018).

In most years during the past decade, Cajamarca has produced more beans and arracacha than any other Colombian municipality, and hence still lives up to its fame as the despensa agricola. However, abundance has come at the cost of an extraordinary dependence on chemical inputs, exposing both the economic and ecological limits of agricultural intensification in the valley. A 2007 report reckoned that the annual arracacha

22. Consistent land-use data has generally proven hard to obtain. Long periods between rural censuses, shifting definitions of what constitutes forests, pastures and scrublands, as well as stark differences even in recent data presented by varying government institutions hinder attempts to survey Anaime's landscape quantitatively over time. 
crop alone absorbed 950 tons of chemical fertilizers; campesinos sprayed as much as 65 tons of active ingredient in fungicides, herbicides and insecticides onto crops and soil annually, many in the form of Class I organophosphorates applied in concentrations three times higher than recommended. Among the impacts of Anaime's agriculture, the report lists soil erosion, depletion of micro and macro organism populations, risks to worker's and public health, high production costs, water contamination and the improper disposal of chemical containers (Semillas de Agua, 2007).

\section{TABLE 4}

Agricultural production and cultivated area of selected crops in Cajamarca, 2018

\begin{tabular}{lccc}
\hline Crop & $\begin{array}{c}\text { Area in } \\
\text { production (ha) }\end{array}$ & $\begin{array}{c}\text { Yield } \\
\text { (kg/ha) }\end{array}$ & $\begin{array}{c}\text { Total } \\
\text { production (kg) }\end{array}$ \\
\hline Arracacha & 4,441 & 12,000 & $53,292,000$ \\
Beans & 3,000 & 12,000 & $3,600,000$ \\
Coffee/Fruit trees & 1,255 & 500 & 627,500 \\
Tomato & 300 & 8,000 & $2,400,000$ \\
Hass avocado & 250 & 30,600 & $7,650,000$ \\
Peas & 220 & 3,000 & 660,000 \\
Gulupa & 200 & 180,000 & $3,600,000$ \\
Curuba (Passiflora tarminiana) & 150 & 14,500 & $2,175,000$ \\
Maize & 65 & 2,500 & 162,500 \\
Granadilla & 50 & 48,500 & $2,425,000$ \\
Tomate de árbol & 50 & 26,000 & $1,300,000$ \\
Red pepper & 40 & 39,000 & $1,560,000$ \\
Andean raspberry (Rubus Glaucus) & 50 & 11,000 & 550,000 \\
Potato & 30 & 16,620 & 498,600 \\
Beets & 30 & 13,000 & 390,000 \\
Cabbage & 20 & 45,000 & 900,000 \\
Onion & 20 & 15,000 & 300,000 \\
Carrot & 20 & 12,000 & 240,000 \\
Cilantro & 15 & 15,000 & 225,000 \\
\hline
\end{tabular}

Source: UMATA (2018).

The spread of the gulupa, though still limited in terms of acreage, is symptomatic of the recent push for high value agricultural exports favored by neoliberal trade policies. Similarly, the Hass avocado has been promoted in the valley with an eye on the European market. These products carry with them a slightly different ecological rucksack. Avocados are produced in expansive monocultures, while in the case of passiflora production, systems are almost invariably partially enclosed in plastic and therefore dependent on an array of improvised irrigation hoses that drain local streams. In the rainy season, covered passi- 
flora plantations -as well as the tomato greenhouses- limit water absorption, increase runoff and contribute to soil erosion.

Though also linked to international markets, coffee production in the Anaime Valley has been subject to two countervailing ecological trends. The nationwide initiative of the National Coffee Growers Federation to renew plantations -replacing Arabigo bushes with more productive and rust-resistant Colombia and Castillo varieties- has often meant felling the complex, traditional systems of coffee and plantains intercropped under shade trees. The shift to fully-exposed monocropping has brought attendant losses in biodiversity, nutrient cycling and protection for the soil.Yet, some producers have bucked the Federation, reforesting their plantations of Arabigo and making ecological sustainability an added value to their premium organic beans. Similarly, campesinos have explored the viability of conservation farming techniques in other crops. Members of the Anaime Watershed Agroecological Farmers Association (APACRA) and other independent producers have turned to agroecology and sought to reestablish diverse agroecosystems against the backdrop of bean and arracacha monoculture.

\section{THE WIDENING METABOLIC RIFT IN ANAIME}

In the preceding pages, the narrative of the transformation of the Anaime Canyon from tropical jungle to Colombia's greengrocer has focused on the linkages between local agrofood production and distant markets in Bogotá, Cali, Armenia and Ibagué. Even in the earliest years of its settlement, visitors to the Anaime Valley such as Julio Liévano and Rafael Uribe Uribe, imagined it as a breadbasket at the service of central Tolima and other distant markets. For the first half of the 1900s, the absence of adequate roads and, to a degree, a lack of sufficient labor operated as limiting factors on the full commercial exploitation of Anaime's soils. Nonetheless, the first ruptures with nature's metabolism began as dairy and livestock production for regional markets carved into the dense forest and coffee was grown for export at lower elevations. Throughout $20^{\text {th }}$ century the expanding physical footprint of agricultural and livestock activities in the valley signaled growing integration into national and regional markets. The mid-century influx of migrants from Cundinamarca and Boyacá with a vocation for commercial agriculture and infrastructure projects that effectively shortened the distances between rapidly growing cities and hinterlands like Anaime cemented the canyon's place in Colombia's expanding urban food systems.

Following O'Connor (1997: 111), infrastructure investment can be seen as productive capital that dramatically reduces transaction costs, shortening turnover time for merchant 
capital, which has dominated Anaime's produce trade from the beginning ${ }^{23}$. New bridges and paved roadways hastened the one-way flow of produce out of the canyon, without providing any return flow of organic material to replenish Anaime's soil, in effect, the most basic definition of the metabolic rift.

The widening metabolic rift in the valley can be traced through both the archival record and the narratives of long-time residents. It manifests itself most clearly through the campesino's growing dependency on chemical and other off-farm inputs required to maintain production, but also through the general deterioration of local ecosystems and agroecosystems and even through recent changes in production relations in certain types of aparcería agreements. The metabolic rift, then, isn't merely a question soil fertility, but the cumulative expression of the rupture between the social metabolism of capitalist commodity production and what Marx called the universal metabolism of nature (Foster, 2013). In Anaime, the rift results from uneven capitalist development, wherein Colombia's industrial urban centers have drawn disproportionately on the resources of outlying territories to feed their growing populations, and thus foisted the environmental load of urban development on the periphery by means of ecologically unequal trade. The ecological rucksacks specific to each of the traded commodities -agro-food production in the case of Anaime- has determined the nature and the magnitude of the load.

Commercial agriculture in the Anaime Valley up until the end of the 1950s relied almost exclusively on the natural fertility of the canyon's volcanic soils, maintained through crop rotation and fallowing. The written accounts of early settlers and the memories of today's older residents describe sowing directly into the thick humus exposed after forest clearing. According to the 1960 Rural Census a mere 129 of Cajamarca's 1,790 total plots used fertilizers of any kind, and only 18 applied synthetic fertilizers (DANE, 1964). Ten years later fertilizer use had become far more prevalent. Villareal and Arias (1970) found that 60 out of 71 plots surveyed used some kind of fertilizer; 39 of these used synthetic fertilizers in some degree. By the early 1990s, campesinos applied $200 \mathrm{~kg}$ of fertilizer (NPK 10-30-10) to each hectare of arracacha (Corpoica, 1994). By 2007, 250 $\mathrm{kg}$ of NPK plus four kilograms of foliating agents were needed to sustain historic yields of $12,000 \mathrm{~kg}$ per hectare. The cost of fertilizer alone represented $9.6 \%$ of total production costs (Semillas de Agua, 2007).

The use of other chemical inputs followed a similar progression. Neither the 1960 nor the 1970-71 agrarian census tracks pesticide use, but Villareal and Arias (1970) found that

23. Mondragón and MotTa (1980) calculate that intermediaries received $40-45 \%$ of the produce's final selling price in Bogotá, as compared to the $20-30 \%$ paid to the producer. 
70 out of 71 campesinos used insecticides at the beginning of the 1970s, and 48 out of 71 used chemicals to control disease, suggesting that insecticide and fungicide use outpaced that of synthetic fertilizers in Cajamarca in the 1960s. By the mid-1990s, campesinos applied between four and five liters of active insecticide ingredients (chlorpyrifos, creolin, and isazofos) on each hectare of arracacha (Corpoica, 1994). By 2007, studies estimated a slightly lower three liters of insecticides (monocrotophos and chlorpyrifos) per hectare, but an additional four kilograms of fungicide (Semillas de Agua, 2007).

The increased use of synthetic fertilizer has stemmed directly from the decades-long export of Anaime's soil nutrients in the form of produce sent to urban markets. The secular trend toward monocropping, the reduction in fallowing and the elimination of traditional crop associations, in which leguminous beans once helped to fix atmospheric nitrogen in the soil, have only aggravated dependency on imported fertility. Increased insecticide use expresses the metabolic rift slightly less directly, as insect and fungal pests are symptomatic of the general deterioration of local agroecosystems. Decreased biodiversity and agrobiodiversity have been among the principle costs of decades of commercial agriculture in Anaime. As land was cleared, simplified agricultural production systems replaced the complex and diverse forest ecosystems. As commercial agriculture selected for the most profitable crops, reductions in crop associations and rotations whittled agrobiodiversity down even further. Insect pests have thrived as natural predators were eliminated both by habitat loss and insecticide use. The application of insecticides with almost no attention to insect life-cycle has allowed local insect population to develop resistance to organophosphorates, while arracacha monoculture and warmer, drier soils resulting from deforestation have created ideal conditions for the chis a population by eliminating fungal and bacterial threats (Lozano, Vásquez \& Sánchez Gutiérrez, 2000). In this sense, increased insecticide use has not only contributed to the degradation of the natural environment in Anaime, but serves as evidence of it.

The use of irrigation for production in the valley follows a similar pattern. In 1960, not a single plot in Cajamarca used irrigation (DANE, 1964). By 1973, researchers observed a small minority of producers in the valley using hoses and aspersion systems on their plots (Villareal \& Arias, 1970). Today, as many as a dozen hoses as large as two inches ${ }^{24}$ in diameter can be found tapping a single pool in the streams of the lower valley. The enclosed and semi-enclosed greenhouse systems for tomato and passiflora production are the biggest consumers, but as once-predictable rainfall patterns have wavered, more producers are watering arracacha and beans as well. The recent tendency toward

24. It should be noted that water concessions granted by CORTOLIMA allow for a $1 / 2$ inch connection to drainages for domestic water consumption. 
exporting avocado and gulupa, the latter with a 90\% water content at harvest (Franco et al., 2013), calls attention to another aspect of the metabolic rift as market-oriented agriculture drains water from Anaime's streams and ships it overseas.

Over decades of specialized market production, Anaime agriculture has co-evolved with the ecosystem it has helped to create, becoming more resource intensive-requiring more fertilizer, water, and pesticides- in response to the deterioration of the local agroecosys$t_{e}{ }^{25}$. In turn, as fertility declined agricultural practice has tended to reduce the soil once the source of Anaime's natural abundance- to a mere physical space and substrate for production, a process evidenced in the reduced relative value of land in aparceria agreements in recent decades. In this sense, production relations too have evolved with the changing ecological conditions of production.

Though scarcer today than in the 1950s, aparceria agreements in arracacha production have adapted over time and, as Gutiérrez Malaxechebarría (2011) argues, have developed into a useful, associative practice that offers potential benefits to both capitalstrapped smallholders and specialized arracach a producers. Of interest here is the decline over the past three decades in the payments accorded to the landowners under a specific variant of aparceria: agreements a la quinta or to the fifth part. Under these agreements, the aparcero assumes greater responsibility and risk in cultivation, putting up labor, food and the inputs required for arracacha production. For his trouble, the aparcero takes home four-fifths of the proceeds from the harvest, while the property owner receives the remaining fifth as payment for the use of his land. However, going a la quinta is derived from the previous norm of going a la cuarta, in which the property owner received a quarter part of the proceeds from sale, common in the early 2000s (Vásquez Acosta \& Norato, 2000; Gutierrez, 2011), when the overall costs of chemical inputs were lower. Most recently, locals report instances of aparcería a la sexta, further reducing the landowner's lot amid the rising cost of inputs and labor. The deterioration in the terms of the aparceria agreements for landowners mirrors declines in the fertility of their land and the quality of local agroecosystems. As more chemical inputs become necessary, the natural fertility of the soil adds less to the value of the harvest relative to other factors of production, suggesting that production relations can be seen as adapting to the steadily widening metabolic rift.

25. The rise in off-farm inputs over the last five decades also evidences the increasingly capital-intensive nature of agriculture in the valley, as industrial capital has appropriated distinct agricultural processes that were once organic to on-farm production in Anaime to create new sites for capital accumulation (GOODMAN, SORJ \& WILKINSON, 1987). 
While in the narrowest sense, the metabolic rift refers to the rupture of the nutrient cycle in the soil, here, the concept has been broadened to include the general degradation of local ecosystems as new farming techniques, technologies and production relations have combined to exhaust or export the local natural environment in an effort to provide salable food to core, urban markets. The rift, then, corresponds to the cumulative ecological costs incurred by peripheral territories like Anaime through ecologically unequal trade with urban centers and is reflected not only in declining soil fertility -and the subsequent dependence on synthetic fertilizers- but also in deforestation, soil erosion and contamination brought on by agricultural intensification, the drain on diminishing water resources and waning biodiversity and agrobiodiversity.

\section{CONCLUSIONS}

The environmental change incumbent in Cajamarca's role as greengrocer to Colombia's urban markets is writ on the slopes of the Anaime watershed. For over one and a half centuries, campesino agriculture and the upland dairies have authored dramatic changes in forest cover, soil composition, local wildlife populations and the flow of the river itself as they've raised food for Bogotá, Cali, Armenia and Ibagué. The environmental history of the valley's integration into the national agro-food market highlights the specific changes wrought on the landscape by ecologically unequal trade with Colombia's core, urban markets. After decades of intensification of commercial agricultural, Anaime's soils have increasingly been reduced to a mere substrate; the fertility and biological controls on pests once inherent in the local ecosystem are now systematically imported in the form of chemical inputs. Local production hinges on upstream linkages to the transnational agrochemical industry, while downstream linkages too have become international in scope with the advent of passiflora and avocado crops for export, suggesting that Anaime's ecologically unequal exchange with new and more distant cores might hasten the opening of the metabolic rift. Yet the contraction of the local dairy herd and the corresponding advance of the Andean forest in the highlands -spurred by the guerrilla's presence and later boosted by institutional conservation efforts- show that environmental change in Anaime has not been linear nor one-directional but depends on a complex array of actors.

The present study signals the value of participatory research methods in environmental history, not only as a data source in regions where the archival record is spotty, but also as a means to open dialogue about the community's past and present relationship with the natural environment. Collective reflection on the evolution of the Anaime Valley among campesinos reveals critical attitudes toward present agricultural practice as well as doubts 
as to its future viability given the rising costs of labor and inputs and the unpredictable nature of market prices.

No doubt, the conflict surrounding La Colosa, AngloGold Ashanti's proposed opencast gold mine in Cajamarca, has sharpened environmental consciousness locally. Since the 2017 plebiscite that rejected mining and prompted AngloGold's provisional departure, many of the organizations that led the battle against La Colosa have questioned the ecological costs of Anaime's intensive agriculture and have turned their efforts toward promoting agroecology and organic agriculture as options for Cajamarca's development. Additionally, a number of younger campesinos have begun probing the collective memory of Anaime's agrarian past and exploring the potential of earlier agroecosystems and cultivation techniques for developing a gentler agriculture for the future. To a large degree, the fate of La Colosa, perceived as a threat not only to Anaime's soil and water, but to continued campesino existence in area, will determine whether this debate over agricultural practice is allowed to continue, or whether Cajamarca's landscape is again to be dramatically recast, this time by an ecologically unequal gold trade whose destructive potential is infinitely greater.

\section{ACKNOWLEDGMENTS}

The author would like to thank Historia Agraria's editorial board and the anonymous reviewers for their valuable comments on previous versions of this paper. Their suggestions have helped to improve both the concision and the clarity of the article's central argument, as have the revisions kindly offered by my father, Richard C. Doughman II. The author would also like to thank the members of the Anaime community for their generous and enthusiastic participation in every phase of the research process. Warm thanks in particular go to NodierVivas and the Muisca Foundation for their insights while accompanying workshops and field work in the community. Financial support was provided by the University of Ibagué.

\section{REFERENCES}

Alcaldía Municipal de Cajamarca (2012). Plan de desarrollo, 2012-2015: Para volver a creer. http://www.cajamarca-tolima.gov.co/planes/plan-de-desarrollo-2012-2015para-volver-a-creer

Arce, C., Castellanos, R. E.., Figueroa, L. \& Rivera, J. J. (2000). Planificación del muestreo para la selección de áreas de trabajo en el sistema de producción de clima 
medio, economía campesina, con cultivos de arracacha en Cajamarca, Tolima. Revista Nataima, (55), 27-36.

AusDal, S. van (2009). Potreros, ganancias y poder: Una historia ambiental de la ganadería en Colombia, 1850-1950. Historia Crítica, (Extra 1), 126-49.

Ausdal, S. van (2012). Productivity Gains and the Limits of Tropical Ranching in Colombia, 1850-1950. Agricultural History, 86 (3), 1-32.

BunkeR, S. G. (2007). Natural Values and the Physical Inevitability of Uneven Trade under Capitalism. In A. F. Hornborg, J. R. McNeill \& J. Martínez Alier (Eds.), Rethinking Environmental History: World-System History and Global Environmental Change (pp. 239-58). Lanham: Altamira.

CoRABAstos (1996). Comportamiento de precios mercado mayorista, 1991-1995. Bogotá: Corporación de abastos de Bogotá S.A.

CoRPOICA (1994). Programa de investigación en el cultivo de arracacha. Working paper. Ibagué: Corpoica-Creced Norte Tolima.

Departamento Administrativo Nacional de Estadística (DANE), Contraloría General de la República (1942). Censo general de población 1938: Resumen general del país. Bogotá: Imprenta Nacional.

Departamento Administrativo Nacional de Estadística (DANE) (1954). Censo de población de Colombia 1951: Resumen. Bogotá: Imprenta Nacional.

Departamento Administrativo Nacional de Estadística (DANE) (1964). Directorio nacional de explotaciones agropecuarias (Censo agropecuario) 1960: Departamento del Tolima. Bogotá: Imprenta Nacional.

Departamento Administrativo Nacional de Estadística (DANE) (1967). XII Censo general de población 1964: Resumen general. Bogotá: Imprenta Nacional.

Departamento Administrativo Nacional de Estadística (DANE) (1974). Censo nacional agropecuario 1970-1971: Cundinamarca, Tolima, Huila. Bogotá: DANE.

Departamento Administrativo Nacional de Estadística (DANE) (1978). XIV Censo general de población y III de vivienda 1973: Resumen general. Bogotá: DANE. Departamento Administrativo Nacional de Estadística (DANE) (1994). XVI Censo nacional de población y V de vivienda 1993: Resumen general. Bogotá: DANE.

Departamento Administrativo Nacional de Estadística (DANE) (2016). III Censo nacional agropecuario. http://www.dane.gov.co/files/CensoAgropecuario/entrega-definitiva/Boletin-1-Uso-del-suelo/1-Anexos-municipales.xls

Departamento Administrativo Nacional de Estadística (DANE) (2018). Censo 2005: Sistema de consulta de información censal. http://systema59.dane.gov.co/ cgibin/RpWebEngine.exe/PortalAction?\&MODE=MAIN\&BASE=CG2005BASICO\&MAIN=WebServerMain.inl

DiETz, C. (2018). Consultas populares mineras en Colombia: Condiciones de su realización y significados políticos: El caso de La Colosa. Colombia Internacional, (93), 93-117. 
FEDERACión COLOMBIANA DE GANADEROS (FEDEGAN) (2014). Foro ganadería regional visión 2014-2018: Tolima, resumen y conclusiones. http://estadisticas.fedegan.org.co/ DOC/download.jsp?pRealName $=11$.PlanTolimaFINAL.pdf\&iIdFiles $=658$

FonsECA, J. I. \& BERNAL, J. A. (1969). Algunos sistemas de manejo en el ganado lechero en cuatro hatos del Corregimiento de Anaime. Unpublished undergraduate thesis. Ibagué: Universidad de Tolima.

Foster, J. B. (1999). Marx's Theory of Metabolic Rift: Classical Foundations for Environmental Sociology. American fournal of Sociology, 105 (2), 366-405.

Foster, J. B. (2000). Marx's Ecology: Materialism and Nature. New York: Monthly Review Press.

Foster, J. B. (2013). Marx and the Rift in the Universal Metabolism of Nature. Monthly Review, 65 (7). https://monthlyreview.org/2013/12/01/marx-rift-universal-metabolism-nature/

Franco, G., Cartagena, J., Correa, G. A. \& Lobo, M. (2013). Physical Characterization of Gulupa Fruits (Passiflora edulis Sims) during Ripening and Postharvest. Revista Agronomía, 21 (1), 48-62.

Gallini, S. (Ed.) (2015). Semillas de historia ambiental. Bogotá: Universidad Nacional de Colombia.

GARCÍA, J. \& CORTÉS, V. H. (1973) Estudio y análisis del proceso de comercialización de productos hortícolas en la zona de Anaime, Cajamarca, Departamento del Tolima. Unpublished undergraduate thesis. Ibagué: Universidad de Tolima.

Goodman, D., SorJ, B., \& Wilkinson, J. (1987). From Farming to Biotechnology: A Theory of Agro-Industrial Development. London: Basil Blackwell.

GutiéRREZ MALAXECHEBARRÍA, A. M. (2011). Nueva aparcería en la producción de arracacha (arracacia xanthorrhiza) en Cajamarca (Colombia). Cuadernos de Desarrollo Rural, 8 (67), 205-28.

Hornborg, A. (2007a). Introduction: Environmental History as Political Ecology. In A. Hornborg, J. R. MCNeILl \& J. MARTínez Alier (Eds.), Rethinking Environmental History:World-System History and Global Environmental Change (pp. 1-24). Lanham: Altamira.

Hornborg, A. (2007b). Footprints in the Cotton Fields: The Industrial Revolution as Time-Space Appropriation and Environmental Load Displacement. In A. HoRNBORG, J. R. McNeill \& J. Martínez Alier (Eds.), Rethinking Environmental History: World-System History and Global Environmental Change (pp. 259-72). Lanham: Altamira.

Instituto Geográfico Agustín CodAZZi (IGAC) (1974). Estudio general de suelos, para fines agrícolas, de los municipios de Ibagué, Cajamarca, Rovira, Alvarado, Anzoátegui, y Santa Isabel (Departamento de Tolima). Bogotá: IGAC. 
Instituto GEOGRÁFico Agustín CoDAZZi (IGAC) (1976). Estudio general de grados de erosión y de cobertura vegetal de la cuenca del río Coello (Departamento de Tolima). Bogotá: IGAC.

Jiménez, N., Doughman, R. \& Montoya, L. (2017). Las Cajamarcas: El Buen Vivir como tejido de lazos alternativos al extractivismo y a los conflictos eco-territoriales en Colombia y Perú. Crítica y resistencias, (5), 76-92.

Kalmanovitz, S. \& López Enciso, E. (2006). La Agricultura colombiana en el siglo XX. Bogotá: Banco de la Republica.

LEAL, C. (2005). Un puerto en la selva: Naturaleza y raza en la creación de la ciudad de Tumaco, 1860-1940. Historia Crítica, (30), 39-65.

Lozano, M. D., VÁsquez Acosta, N. C. \& SÁnChez GutiérRez, G. (2000). Selección de cepas nativas de Metarhizium anisopliae (Metch) Sorokin sobre varios géneros de chisas (Coleoptera: Melolonthidae) en el cultivo de la arracacha (Arracacia xanthorriza). Revista Nataima, (55), 27-36.

Machado, A. (1986). Políticas agrarias en Colombia 1900-1960. Bogotá: Centro de Investigaciones para el Desarrollo.

MARIN, J. I. (Ed.) (2013). Algunas voces, algunas manos: Centenario de la fundación marzo 27 de 1913-marzo 27 de 2013. Cajamarca: Alcaldía Municipal de Cajamarca.

Martínez Alier, J. (2007). Marxism, Social Metabolism and International Trade. In A. Hornborg, J. R. MCNeILl \& J. Martínez Alier (Eds.), Rethinking Environmental History:World-System History and Global Environmental Change (pp. 221-37). Lanham: Altamira.

MARTínez Alier, J. (2008). Conflictos ecológicos y justicia ambiental. Papeles de relaciones ecosociales y cambio global, (103), 11-27. https://www.fuhem.es/media/cdv/file/biblioteca/PD\%20Papeles/103/Conflictos_ecologicos_justicia_ambiental.pdf

Marull, J., Delgadillo, O., Cattaneo, C., la Rota, M. J. \& Krausmann, F. (2018). Socioecological Transition in the Cauca RiverValley, Colombia (1943-2010): Towards an Energy-Landscape Integrated Analysis. Regional Environmental Change, 18(4), 1073-1087. https://doi.org/10.1007/s10113-017-1128-2

Marx, K. (1991 [1894]). Capital: A Critique of Political Economy. Vol. III. London: Penguin Books.

Ministerio de Agricultura (2018). Evaluaciones agropecuarias municipales. http://www.agronet.gov.co/estadistica/Paginas/default.aspx

MondRAGÓN, G. \& MotTA, O. G. (1980). Estudio de factibilidad para el establecimiento de un centro de acopio en Anaime, Cajamarca-Tolima. Unpublished undergraduate thesis. Ibagué: Universidad de Tolima.

Moore, J. W. (2003). "The Modern World-System" as Environmental History? Ecology and the Rise of Capitalism. Theory and Society, 32 (3), 307-77. 
OcAmpo, J. A. (Ed.) (2015). Historia económica de Colombia. (4 $4^{\text {th }}$ edition). Bogotá: Fondo de Cultura Económica.

O'Connor, J. (1997). Natural Causes: Essays in Ecological Marxism. New York: Guilford Press.

Palacio, G. et al. (2001). La naturaleza en disputa. Bogotá: Universidad Nacional de Colombia.

Palacio, G. (2006). Fiebre de tierra caliente: Una historia ambiental de Colombia 18501930. Bogotá: ILSA.

Palacio, G. \& Ruiz Soto, M. F. (Eds.) (2008). Historia ambiental de Bogotá y la Sabana, 1850-2005. Bogotá: Universidad Nacional de Colombia, sede Amazonía.

PAvA, S. DE LA (1991). Este es mi testimonio: Novela. Ibagué: El Poira Editores e Impresores.

PAVA, S. DE LA (2002). Los patriarcas del campo: Novela. Ibagué: El Poira Editores e Impresores.

PÉrez Rincón, M. A. (2006). Colombian International Trade from a Physical Perspective: Towards an Ecological "Prebisch Thesis". Ecological Economics, 59 (4), 519-29.

Rodríguez, J. E., Infante, A. H., Bracho, L. A., Bocanegra, A. \& Prieto, R. E. (1974). Proyecto de desarrollo rural para el cañón de Anaime. Unpublished undergraduate thesis. Ibagué: Universidad de Tolima.

Salgado, H. \& Gómez García, A. N. (2000). Pautas de asentamientos prehispánicas en Cajamarca-Tolima. Bogotá: Banco de la República.

SÁNCHEZ GarCíA, D. P. (2013). Minería, territorio y territorialidad: El caso del hallazgo aurífero La Colosa en el municipio de Cajamarca (Tolima-Colombia) 2000-2013. http://bdigital.unal.edu.co/45135/1/52817248.2013.pdf

Semillas de agua (2007). Diagnóstico y plan de trabajo para reducir el impacto del uso de agroquímicos en el cultivo de arracacha en la cuenca alta del río Coello, Tolima. Calí: Corporación Semillas de Agua.

Tovar, A. (1981). Investigaciones arqueológicas en el cañón de Anaime. Bogotá: Fundación de investigaciones arqueológicas nacionales, Banco de la República.

UMATA (2018). Producción de los cultivos, Cajamarca-Tolima. Cajamarca: Unidad Municipal de Asistencia Técnica Agropecuaria.

Unidad Regional de Planificación Agropecuaria (URPA) (1989). Estadísticas básicas municipales-Cajamarca. Ibagué: Secretaria de Desarrollo del Tolima.

VÁsquez ACOSTA, N. \& NorATo,T. (2000).Validación y transferencia de tecnología para el microbiológico control de las chisas en el sistema de producción de arracacha de Cajamarca. Revista Nataima, (55), 5-18.

VÁsquez AcostA, N. \& GuTiÉRREZ, D. (2000). Fertilización y distancias de siembra en el cultivo de arracacha en el municipio de Cajamarca, Tolima. Revista Nataima, (55), 57-64. 
Villareal, H. \& ARIAS, R. (1970). Estudio agro-socio-económico del cañón de Anaime, municipio de Cajamarca. Unpublished undergraduate thesis. Ibagué: Universidad de Tolima.

Wittman, H. (2009). Reworking the Metabolic Rift: La Vía Campesina, Agrarian Citizenship, and Food Sovereignty. The fournal of Peasant Studies, 36 (4), 805-26. 